\title{
EFFECTS OF SOIL UNDER THE CANOPY OF AZADIRACHTA INDICA (NEEM) AND KHAYA SENEGALENSIS L (MAHOGANY) AND INORGANIC FERTILIZER ON GROWTH AND DEVELOPMENT OF MAIZE (ZEA MAYS)
}

\author{
Kyari, Emmanuel Multafu \\ Department of Applied Ecology Abubakar Tafawa Balewa University Bauchi, Nigeria. \\ Mbaya, Yusuf Arhyel., \\ Department of Geography Federal University Gashua, Yobe Nigeria. \\ Umar, Kamfut Hassan \\ Department of Applied Ecology Abubakar Tafawa Balewa University Bauchi, Nigeria. \\ Olajemilo, Modupe, Eunice. \\ Department of Applied Ecology Abubakar Tafawa Balewa University Bauchi, Nigeria.
}

Musa Umar

Department of Biology Abubakar Tafawa Balewa University Bauchi, Nigeria.

Ramesh. Kumar

Conduent Business Services India LLP, Bangalore. India

\begin{abstract}
This experiment was conducted to evaluate the beneficial effects (if any) of Azadirachta Indica (neem) and Khaya Senegalensis L (Mahogany) tree litter on soil under the tree canopy for growth of maize and to determine the best tree species to use based on integrated farming system for crop production. Pots filled $2.5 \mathrm{~kg}$ soil collected Under the two tree species and the sample from open space from a similar farm were arranged in a completely randomized design with three replication. Four seed of Maize cultivars (Oba98 \& Oba super) were planted in the pots. The maize seeds germinated after five days and were thin to one per pot, adequate irrigation maintained to moist throughout the experimental period and compound fertilizer (NPK 15-15-15) corresponding to $200 \mathrm{~kg} / \mathrm{ha}^{-1}$ were applied (2weeks after days of sowing). The result revealed that
\end{abstract}

Maize cultivars are grown on soil collected from under the canopy of the two tree species and fertilized NPK corresponding to $200 \mathrm{~kg} / \mathrm{ha}^{-1}$ substantially improved the plant height, leaf length and shoot and root dry weights than soil collected from the under tree species unfertilized and sandy-loam soil fertilized.

Key Words: Plant litter; Azadirachta Indica (neem), Khaya Senegalensis L (Mahogany); Maize; Soil fertility

\section{INTRODUCTION}

Plant litter is the fastest way of adding organic matter and nutrients to the soil. (Hossain et al., 2011; Mason,1977; Park and Kang-Hyun, 2003). Microorganism play key role in decomposition and physical leaching of soluble components followed by 
microbial oxidation of refractory components (Mason,1977; Mahmmod et al., 2014; Valiela et al., 1985; Hasanuzzaman, 2014). The nutrient content of the plant litter added to the soil depends on individual species to another (Mahmmod et al., 2014; Benton Jones, 1998; Marchner, 1995). The quantity of nutrient accumulation to an ecosystem is reported to differ from individual species to another and supported by climate conditions (Mahmood and Saberi, 2005; Mahmmod et al., 2014; Seinwal et al., 2003). Suitable tree species choice established on nutrient cycling is important in agroforestry practice (Benton Jones, 1998). Plant litter comprises of different classes of organic compounds. Four major association of organic material has been reported in the litter: sugar, phenolics, hydrocarbon and glycerides, The solvable sugars, primarily mono and oligosaccharides are difficult to metabolize (Kruse $e t$ al., 2000). These compounds action depends on the concentrations (Einhellig, 1986) this can affect the plant growth when at higher concentrations and also when at a lower concentration, promote plant growth. This inhibitory behavior is attributed to the blockage or cessation of key physiological and metabolic processes of the plant. These allelochemicals on the other hand support growth and also trigger resistance to several abiotic stresses (Farooq et al., 2009a, 2009b). Comparative sizes of these combinations vary with the plant part (leaves, stems, roots, bark) and plant species. The plant litter value is measured using chemical contents of nitrogen, phosphorus, potassium and principal cell wall components, such as lignin, cellulose, and hemicelluloses that influence the litter decomposition and nutrient release (Swift et al., 1979).
In research conducted by Mubarak et al. (2009), the findings reported that Khaya Senegalensis $L$. (Mahogany)litter has the chemical composition of $\mathrm{N}=32.9, \mathrm{P}=2.4, \mathrm{~K}=33, \mathrm{Ca}=14, \mathrm{Mg}=2.0, \mathrm{C}=450$, $\mathrm{C} / \mathrm{N}=137$, Lignin=17.4, and cellulose $=25.0$, and Azadirachta Indica (neem) litter was reported to have $\mathrm{N}=46.9, \mathrm{P}=3.6, \mathrm{~K}=7.7, \mathrm{Ca}=9.3, \mathrm{Mg}=2.8, \mathrm{C}=420$, $\mathrm{C} / \mathrm{N}=9$, Lignin $=16.5$, and cellulose $=19.9$. Research in Burkina Faso has revealed that mulching sorghum with neem litter enhanced sorghum yields by up to $422 \%$ of the unmulched control (Tilander, 1993). Laboratory studies indicated that Azadirachta Indica(neem) biomass contained nitrogen content of $2.07 \%, 0.12 \%$ of phosphorous, $0.20 \%$ of potassium, $0.61 \%$ of calcium and $0.22 \%$ of magnesium, the biomass was applied together with NPK fertilizer. One hundred and twenty (120) kg of NPK fertilizer/ha significantly produced the highest maize grain yield of $3 \mathrm{t} / \mathrm{ha}$ than all the treatments. The same grain yield of $1.8 \mathrm{t} / \mathrm{ha}$ was obtained for $6 \mathrm{t} / \mathrm{ha}$ of biomass $\left(\mathrm{T}_{1}\right), 4 \mathrm{t} / \mathrm{ha}$ of biomass plus $40 \mathrm{~kg}$ of NPK fertilizer/ha $\left(\mathrm{T}_{5}\right)$, and $3 \mathrm{t} / \mathrm{ha}$ of biomass plus $60 \mathrm{~kg}$ of NPK fertilizer/ha $\left(\mathrm{T}_{4}\right)$ which recorded the secondhighest maize yield. 3t/ha of biomass gave maize yield of $1.2 \mathrm{t} / \mathrm{ha}$. All the treatments were significantly different from the control. The control had the least grain yield of $0.5 \mathrm{t} / \mathrm{ha}$. The highest level of NPK fertilizer application (120 kg/ha) significantly produced the highest maize height $(170.2 \mathrm{~cm})$. Also, $6 \mathrm{t} /$ ha of biomass $\left(\mathrm{T}_{1}\right), 3 \mathrm{t} / \mathrm{ha}$ of biomass with $60 \mathrm{~kg}$ of NPK fertilizer/ha $\left(\mathrm{T}_{4}\right), 4 \mathrm{t} / \mathrm{ha}$ of biomass with $40 \mathrm{~kg}$ of NPK fertilizer/ha $\left(\mathrm{T}_{5}\right)$, were not significantly different but were significantly higher than $3 \mathrm{t} / \mathrm{ha}$ of biomass $\left(\mathrm{T}_{2}\right)$, and the control (Rafiu, 2012).

Table 1: Nutrient content of Azadirachta indica (neem) and Khaya Senegalensis (Mahogany) litter

\begin{tabular}{|l|l|l|l|l|l|l|l|l|l|l|}
\hline SN & Plant species & $\mathbf{N}$ & $\mathbf{P}$ & $\mathbf{K}$ & $\mathbf{C a}$ & $\mathbf{M g}$ & $\mathbf{C}$ & $\mathbf{C} / \mathbf{N}$ & Lignin & Cellulose \\
\hline 1 & $\begin{array}{l}\text { Azadirachta indica } \\
\text { (neem) }\end{array}$ & 46.9 & 3.6 & 7.7 & 9.3 & 2.8 & $\begin{array}{l}42 \\
0\end{array}$ & 9 & 16.5 & 19.9 \\
\hline 2 & $\begin{array}{l}\text { Khaya Senegalensis } \\
\text { (Mahogany) }\end{array}$ & 32.9 & 2.4 & 33 & 14 & 2.0 & $\begin{array}{l}45 \\
0\end{array}$ & 13.7 & 17.4 & 25.0 \\
\hline
\end{tabular}

Source: Mubarak et al. (2009)

Mukaromah et al. (2016) reported Mahogany (S. macrophylla King) litter concentration was concomitant with inhibition radicle seedling growth compared to control. In most of the research on resource quality characterization, decomposition, and nutrient release, the focus has been put on leguminous plant species which are known to have high-quality materials (Cadisch and Giller, 1997). Non-leguminous plant species like Azadirachta Indica (neem) and Khaya Senegalensis L (Mahogany) can improve soil fertility and organic matter status of the soils. (Table 1). Despite the considerable importance of non-leguminous plant species in improving soil fertility and organic matter status of 
soils, few attempts have been made to quantitatively determine the effects of Mahogany and neem litter as a nutrient source for maize production. To evaluate the effects Mahogany and neem have on food crops, surface soil under Mahogany and neem tree was used to grow Maize. The findings indicated that two months after planting, the crops produce five times higher biomass on the soil from the neem plantation than on the control. The trees had favorable effects on soil fertility and therefore improved crop yield (Verinumbe, 1991). Azadirachta Indica (neem)and Khaya Senegalensis L (Mahogany) is one of the most widely planted exotic species on nutrient-deficient soils in Northern Nigeria. Azadirachta Indica (neem) and Khaya Senegalensis L (Mahogany) has acclimatized well throughout Northern Nigeria and is popular as a source of firewood and as poles and rafters for building construction as well as the provision of shade. Azadirachta Indica (neem) and Khaya Senegalensis L (Mahogany) extracts are also valued for their medicinal properties in treating malaria and as an insecticide for protecting grain. The leaves, together with the twigs, can be applied as mulch or incorporated into the soil as organic input to provide nutrients to crops. However, little or no attempt has been taken to screen or prioritize the commonly planted tree species in the cropland agroforests as well as other types of agroforestry based on nutrient cycling. The objectives of this study were: (1) to determine the effectiveness of litter decomposition on soil as regard to maize production for two commonly planted horticultural agroforestry tree species Azadirachta indica (neem) and Khaya Senegalensis L (Mahogany) (2) to determine the best tree species to use based on integrated farming system for crop production.

\section{MATERIALS AND METHODS}

\subsection{Experimental site}

The experiment was conducted at the department of applied ecology screen House located at $10^{\circ} 16^{\prime} \mathrm{N}$, and $9^{\circ} 47^{\prime} 19^{\circ} \mathrm{E}$ of Abubakar Tafawa Balewa University Yelwa Campus, Bauchi State Nigeria.

\subsection{Collection and planting of seeds}

Seeds of OBA98 and OBA SUPER for the experiment were obtained from Bauchi State Agricultural Development Program (BSADP).

\subsection{EXPERIMENTAL Procedure}

Soil sample for the experiment was collected $15 \mathrm{~cm}$ deep directly under the roots and $100 \mathrm{~cm}$ away from of Azadirachta Indica (neem) and Khaya Senegalensis L (Mahogany)trees in the agricultural research farm of Abubakar Tafawa Balewa University. The soil sample collected for each tree species was mixed $(15 \mathrm{~cm}$ deep and $100 \mathrm{~cm}$ away), the sample of sand-loam soil was collected from the same farm in open space. $2.5 \mathrm{~kg}$ of the soil sample was filled in pots arranged in a completely randomized design with three replication. The maize seed was sterilized in $10 \%$ Na-hypochlorite solution for 20 minutes to prevent fungal growth and then washed with distilled water (Di salvatiCarafa et al., 2008). Three maize seeds were directly planted in each pot after the pots containing the soil were wet with water. The maize seeds germinated after five days and were thin to one per pot, adequate irrigation maintained to moist throughout the experimental period and compound fertilizer (NPK 15-15-15) corresponding to $200 \mathrm{~kg} / \mathrm{ha}^{-1}$ were applied (2weeks after days of sowing). The experimental layout was as follows:

$\mathbf{T}_{\mathbf{1}}$ : OBA98 in Azadirachta Indica +NPK. (200kg/ha 1)

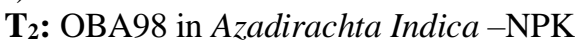

T3: $_{3}$ OBA Super in Azadirachta Indica+NPK $\left(200 \mathrm{~kg} / \mathrm{ha}^{-1}\right)$.

T$_{4}$ : OBA Super in Azadirachta Indica -NPK

T5: OBA98 in Khaya Senegalensis $L+\mathrm{NPK}$ $\left(200 \mathrm{~kg} / \mathrm{ha}^{-1}\right)$

T6: OBA98 in Khaya Senegalensis $L-\mathrm{NPK}$

$\mathbf{T}_{7}$ : OBA Super in Khaya Senegalensis L+NPK $\left(200 \mathrm{~kg} / \mathrm{ha}^{-1}\right)$

T8: OBA Super in Khaya Senegalensis $L$-NPK

T9: OBA98 in Sandy-loam+NPK $\left(200 \mathrm{~kg} / \mathrm{ha}^{-1}\right)$

$\mathbf{T}_{10}$ OBA Super in Sandy-loam+NPK $\left(200 \mathrm{~kg} / \mathrm{ha}^{-1}\right)$

\subsection{Data collection}

2.4.1 Plant height: The plant height was recorded using a measuring tape. It was measured from the soil surface to the highest point of the arch of the uppermost leaf whose tip was pointing down Guzaman and Lamkey, 2000 [9].

2.4.2 Leaf length: Leaf length was measured to the nearest millimeter from the leaf tip to the point at which the lamina is attached to the petiole Ismail et al., 2009 
2.4.3 Dry shoot and root mass: After 45days sowing, the maize plant harvested and the soil was washed off the roots, then separated from the shoots with sharp knife and was put into brown envelope for oven drying at $70^{\circ} \mathrm{C}$ for 48 hours to a constant weight, shoot and root dry weight mass was measured using digital weighing balance and recorded. (Kyari et al., 2019).

\subsection{Statistical analysis}

Data collected were subjected to ANOVA using Minitab version 16. The difference between treatments was tested on plant height, leaf length, shoot and root dry weight.

\subsection{Results and Discussion}

The trees play an important role in improving soil fertility and which can lead to an improvement in crop yield output (Verinumbe, 1991). It is equally important to identify tree species with good biomass in the farm vicinity to reduce the labor cost of improving soil fertility. Such plant species be supposed to have the ability to add to phosphorus availability to crops because organic inputs contain low phosphorous contents (Palm et al., 1997). The results of our present study as shown in table 2, showed that in the plant height, $\mathrm{T}_{1}$ : OBA98 planted in Azadirachta Indica soil+NPK $\left(200 \mathrm{kh} / \mathrm{ha}^{-1}\right)$ recorded $107.73 \mathrm{~cm}$, while $\mathrm{T}_{2}$ : OBA98 in Azadirachta Indica soil $-\mathrm{NPK}$ recorded $77.63 \mathrm{~cm}$, also $\mathrm{T}_{3}$ : OBA Super in Azadirachta Indica soil +NPK recorded $100.37 \mathrm{~cm}$, $\mathrm{T}_{4}$ : OBA Super in Azadirachta Indica soil -NPK was $77.63 \mathrm{~cm}, \mathrm{~T}_{5}$ : OBA98 in Khaya Senegalensis $L$ soil $+\mathrm{NPK}$ it was $98.63 \mathrm{~cm}, \mathrm{~T}_{6}$ : OBA98 in Khaya Senegalensis $L$ soil $-\mathrm{NPK}$ was $96.93 \mathrm{~cm}, \mathrm{~T}_{7}$ : OBA Super in Khaya Senegalensis $L$ soil +NPK90 has $17 \mathrm{~cm}, \mathrm{~T}_{8}$ : OBA Super in Khaya Senegalensis L soil NPK was $78.37 \mathrm{~cm}, \mathrm{~T}_{9}$ : OBA98 in Sandy-loam soil + NPK7 recorded $76.33 \mathrm{~cm}$, and $\mathrm{T}_{10}$ OBA Super in Sandy-loam soil +NPK $58.57 \mathrm{~cm}$. Comparing between the treatments, maize cultivar OBA98 $\left(\mathrm{T}_{1}\right)$ planted in the soil collected under Azadirachta Indica (neem) tree with application of $200 \mathrm{~kg} / \mathrm{ha}^{-1}$ NPK significantly recorded higher mean plant height than all the treatments. The results of the research found that plant height was higher in the soil collected under the two tree species (Azadirachta Indica and Khaya Senegalensis L.) with the addition of $200 \mathrm{~kg} / \mathrm{ha}^{-1}$ NPK. Although it was closely followed by soil collected under the tree but without the addition of NPK as compared to sandy-loam soil with the addition of $200 \mathrm{~kg} / \mathrm{ha}^{-1}$ NPK. The higher plant height recorded in the soil collected under the trees could be due to the decomposed litter that was added to the soil by the plants. The results of our experiment agree with the report of Verinumbe, (1991) that trees had favorable effects on soil fertility and therefore improved crop yield. However, in the leaves length $\mathrm{T}_{1}$ : OBA98 planted in Azadirachta Indica soil+NPK $\left(200 \mathrm{kh} / \mathrm{ha}^{-1}\right)$ recorded $83.77 \mathrm{~cm}$ and $\mathrm{T}_{2}$ : OBA98 in Azadirachta Indica soil -NPK $65.20 \mathrm{~cm}$, while $\mathrm{T}_{3}$ : OBA Super in Azadirachta Indica soil $+\mathrm{NPK}$ recorded $82.07 \mathrm{~cm}$, and $\mathrm{T}_{4}$ : OBA Super in Azadirachta Indica soil -NPK was $60.27 \mathrm{~cm}$, then $\mathrm{T}_{5}$ : OBA98 in Khaya Senegalensis $L$ soil +NPK $82.03 \mathrm{~cm}, \mathrm{~T}_{6}$ : OBA98 and Khaya Senegalensis $L$ soil $-\mathrm{NPK} 65.20 \mathrm{~cm}$. Also $\mathrm{T}_{7}$ : OBA Super in Khaya Senegalensis $L$ soil $+\mathrm{NPK}$ was $77.83 \mathrm{~cm}$ and $\mathrm{T}_{8}$ : OBA Super in Khaya Senegalensis L soil -NPK $63.27 \mathrm{~cm}$, $\mathrm{T}_{9}$ : OBA98 in Sandy-loam soil +NPK59.47cm, and $\mathrm{T}_{10}$ OBA Super in Sandy-loam soil +NPK $59.47 \mathrm{~cm}$. Maximum leaf length value was recorded in $T_{1}$ followed by $T_{3}, T_{4}$, and $T_{7}$ where the soil sample was collected under the trees canopy with application of $200 \mathrm{kh} / \mathrm{ha}^{-1}$ of NPK. More also, maize cultivars raise on soil samples collected directly under the tree canopy without application of NPK gave appreciable leaf length when compared to those raised on sandy loam with $200 \mathrm{kh} / \mathrm{ha}^{-1}$ of NPK (Table 2). Here, our study found that the integrative effects of soil organic matter and inorganic fertilizer has improved on maize productivity and we also found that combined application of both organic and inorganic sources of nutrients can improve growth and other yield-related attributes of maize (Table 2). The outcome of the findings also showed that the Azadirachta Indica tree is a good species that can be integrated with maize on the same land in terms of maize production. Our results corrugate with the findings reported by Mubeen et al. (2013), that combined application of organic and inorganic fertilizers is considered a good option to enhance nutrient recovery, plant growth, and ultimate yield otherwise higher $\mathrm{N}$ and $\mathrm{P}$ application rates are required to attain better yield in maize.

Furthermore, in the dry shoot mass $\mathrm{T}_{1}$ : OBA98 planted in Azadirachta Indica soil+NPK $\left(200 \mathrm{kh} / \mathrm{ha}^{-1}\right)$ recorded $25.63 \mathrm{~g}$ and $\mathrm{T}_{2}$ : OBA98 in Azadirachta Indica soil -NPK $8.70 \mathrm{~g}$, while $\mathrm{T}_{3}$ : OBA Super in Azadirachta Indica soil +NPK recorded 26.63, and $\mathrm{T}_{4}$ : OBA Super in Azadirachta Indica soil -NPK was $8.70 \mathrm{~g}$, then $\mathrm{T}_{5}$ : OBA98 in Khaya Senegalensis $L$ soil +NPK $17.97 \mathrm{~g}, \mathrm{~T}_{6}$ : OBA98 and Khaya senegalensis $L$ soil -NPK 6.30g. Also $\mathrm{T}_{7}$ : OBA Super in Khaya Senegalensis $L$ soil $+\mathrm{NPK}$ was $9.63 \mathrm{~g}$ and $\mathrm{T}_{8}$ : OBA Super in Khaya Senegalensis L soil -NPK 11.63g, 
$\mathrm{T}_{9}$ : OBA98 in Sandy-loam soil +NPK was $3.77 \mathrm{~g}$, and $\mathrm{T}_{10}$ OBA Super in Sandy-loam soil +NPK 7.30g (Table 2). Substantial improvement in shoot dry weights was observed $T_{3}, T_{4}$, and $T_{5}$ by the application of inorganic fertilizer (Table 2). From the finding, it was deduced that the maximum shoot dry weight was obtained in the soil collected under Azadirachta Indica tree species and fertilized with $200 \mathrm{kh} / \mathrm{ha}^{-1}$ NPK. Improved plant height and leaf area in plants by organic manure applications have been reported (Boateng et al., 2006; Muhammad \& Khattak, 2009). In the dry shoot mass, $\mathrm{T}_{1}$ : OBA98 planted in Azadirachta Indica soil+NPK (200kh/ha- $\left.{ }^{-1}\right)$ recorded $2.90 \mathrm{~g}$ and $\mathrm{T}_{2}$ : OBA98 in Azadirachta Indica soil -NPK 3.63g, while $\mathrm{T}_{3}$ : OBA Super in Azadirachta Indica soil +NPK recorded $5.07 \mathrm{~g}$, and $\mathrm{T}_{4}$ : OBA Super in Azadirachta Indica soil -NPK was $3.60 \mathrm{~g}$, then $\mathrm{T}_{5}$ : OBA98 in Khaya Senegalensis $L$ soil +NPK 4.87g, T6: OBA98 and Khaya Senegalensis L soil -NPK 3.13g. Also $\mathrm{T}_{7}$ : OBA Super in Khaya
Senegalensis $L$ soil $+\mathrm{NPK}$ was $3.07 \mathrm{~g}$ and $\mathrm{T}_{8}$ : OBA Super in Khaya Senegalensis L soil -NPK 4.50g, T9: OBA98 in Sandy-loam soil +NPK was $1.33 \mathrm{~g}$, and $\mathrm{T}_{10}$ OBA Super in Sandy-loam soil +NPK 3.13g. The maximum root dry mass was recorded in $T_{3}$ although not fertilize with NPK but collected under Azadirachta Indica, then $\mathrm{T}_{5}$ and $\mathrm{T} 8$ raised on the soil sample collected from under trees species of Azadirachta Indica and Khaya Senegalensis $L$ fertilized with $200 \mathrm{kh} / \mathrm{ha}^{-1}$ of NPK, followed by $\mathrm{T}_{2}$ and $\mathrm{T}_{3}$, Better root growth is responsible increased nutrient uptake in plants (Aziz et al.,2006). The findings could suggest that the addition of organic matter by the tree litter may the reason for improved root matter. The improved shoot and root growth by the addition of organic manure (Muhammad \&Khattak, 2009; Boateng et al., 2006; Hirzel et al., 2007) might be attributed to improved soil $\mathrm{P}$ and $\mathrm{K}$ availability (Marschner, 1995).

Table 2: Effects of tree litter on soil under canopy soil and inorganic fertilizer on some agronomic characters of $\mathrm{Oba98}$ and Oba Super Maize cultivars.

\begin{tabular}{|c|c|c|c|c|c|c|c|}
\hline $\mathbf{S N}$ & $\begin{array}{l}\text { Maize } \\
\text { Cultivar } \\
\text { s }\end{array}$ & $\begin{array}{l}\text { Soil used } \\
(\mathrm{kg} / \mathrm{pot})\end{array}$ & $\begin{array}{l}\text { Treatment } \\
\text { S }\end{array}$ & $\begin{array}{l}\text { Plant height } \\
\text { (cm/pot) }\end{array}$ & $\begin{array}{l}\text { Leaf length } \\
\text { (cm/pot) }\end{array}$ & $\begin{array}{l}\text { Dry shoot } \\
\text { Mass } \\
\text { (kg/pot) }\end{array}$ & $\begin{array}{l}\text { Dry root } \\
\text { mass } \\
(\mathrm{kg} / \text { pot })\end{array}$ \\
\hline 1 & $\begin{array}{l}\text { OBA98 } \\
\left(\mathrm{T}_{1}\right)\end{array}$ & $\begin{array}{l}\text { Azadirachta } \\
\text { Indica }\end{array}$ & $200 \mathrm{~kg} / \mathrm{ha}^{-1}$ & $4.64 \pm 107.73^{\mathrm{a}}$ & $3.53 \pm 83.77^{\mathrm{a}}$ & $3.51 \pm 25.63^{\mathrm{a}}$ & $0.52 \pm 2.90^{\mathrm{a}}$ \\
\hline 2 & $\begin{array}{l}\text { OBA98 } \\
\left(\mathrm{T}_{2}\right)\end{array}$ & $\begin{array}{l}\text { Azadirachta } \\
\text { Indica }\end{array}$ & - NPK & $25.59 \pm 77.63^{\mathrm{ab}}$ & $14.32 \pm 60.27^{\mathrm{bc}}$ & $0.87 \pm 8.70^{\mathrm{bc}}$ & $1.44 \pm 3.63$ a \\
\hline 3 & $\begin{array}{l}\text { OBA } \\
\text { Super }\left(T_{3}\right)\end{array}$ & $\begin{array}{l}\text { Azadirachta } \\
\text { Indica }\end{array}$ & $200 \mathrm{~kg} / \mathrm{ha}^{-1}$ & $4.24 \pm 100.37^{\mathrm{ab}}$ & $1.90 \pm 82.07^{\mathrm{ab}}$ & $4.62 \pm 26.63^{\mathrm{a}}$ & $3.55 \pm 5.07^{\mathrm{a}}$ \\
\hline 4 & $\begin{array}{l}\text { OBA } \\
\text { Super } \\
\left(T_{4}\right)\end{array}$ & $\begin{array}{l}\text { Azadirachta } \\
\text { Indica }\end{array}$ & - NPK & $25.59 \pm 77.63^{\mathrm{ab}}$ & $14.32 \pm 60.27^{\mathrm{bc}}$ & $1.22 \pm 8.70^{\mathrm{bc}}$ & $1.73 \pm 3.60^{\mathrm{a}}$ \\
\hline 5 & $\begin{array}{l}\text { OBA98 } \\
\left(\mathrm{T}_{5}\right)\end{array}$ & $\begin{array}{l}\text { Khaya } \\
\text { senegalensis }\end{array}$ & $200 \mathrm{~kg} / \mathrm{ha}^{-1}$ & $11.11 \pm 98.63^{\mathrm{ab}}$ & $6.96 \pm 82.03^{\mathrm{ab}}$ & $1.17 \pm 17.97^{\mathrm{ab}}$ & $1.62 \pm 4.87 \mathrm{a}$ \\
\hline 6 & $\begin{array}{l}\text { OBA98 } \\
\left(\mathrm{T}_{6}\right)\end{array}$ & $\begin{array}{l}\text { Khaya } \\
\text { senegalensis }\end{array}$ & - NPK & $11.20 \pm 96.93^{\mathrm{ab}}$ & $4.85 \pm 65.20^{\mathrm{ab}}$ & $3.61 \pm 6.30^{\mathrm{c}}$ & $2.30 \pm 3.13^{\mathrm{a}}$ \\
\hline 7 & $\begin{array}{l}\text { OBA } \\
\text { Super }\left(T_{7}\right)\end{array}$ & $\begin{array}{l}\text { Khaya } \\
\text { senegalensis }\end{array}$ & $200 \mathrm{~kg} / \mathrm{ha}^{-1}$ & $19.72 \pm 90.17^{\mathrm{ab}}$ & $10.19 \pm 77,83^{\mathrm{ab}}$ & $0.31 \pm 9.63^{\mathrm{bc}}$ & $0.47 \pm 3.07^{\mathrm{a}}$ \\
\hline 8 & $\begin{array}{l}\text { OBA } \\
\text { Super }\left(T_{8}\right)\end{array}$ & $\begin{array}{l}\text { Khaya } \\
\text { senegalensis }\end{array}$ & -NPK & $13.32 \pm 78.37^{\mathrm{ab}}$ & $6.39 \pm 63.27^{\mathrm{abc}}$ & $8.02 \pm 11.63^{\mathrm{bc}}$ & $0.79 \pm 4.50^{\mathrm{a}}$ \\
\hline 9 & $\begin{array}{l}\text { OBA98 } \\
\left(\mathrm{T}_{9}\right)\end{array}$ & Sandy-loam & $200 \mathrm{~kg} / \mathrm{ha}^{-1}$ & $1.53 \pm 76.33^{\mathrm{ab}}$ & $0.47 \pm 59.47^{\mathrm{bc}}$ & $0.85 \pm 3.77^{\mathrm{c}}$ & $0.70 \pm 1.33^{\mathrm{a}}$ \\
\hline 10 & $\begin{array}{l}\text { OBA } \\
\text { Super } \\
\left(T_{10}\right)\end{array}$ & Sandy-loam & $200 \mathrm{~kg} / \mathrm{ha}^{-1}$ & $3.00 \pm 58.57^{\mathrm{b}}$ & $0.91 \pm 41.97^{\mathrm{c}}$ & $2.21 \pm 7.30^{\mathrm{c}}$ & $1.04 \pm 3.13^{\mathrm{a}}$ \\
\hline
\end{tabular}

Means that do not share a letter are significantly different. - means no inorganic fertilizer. OBA98 (Obasanjo Maize bread), OBA Super (Obasanjo maize bread).

\section{CONCLUSION}

The soil collected under the canopy of Azadirachta Indica (neem) and Khaya senegalensis (Mahogany) tree combined with NPK fertilizer produced substantial plant height, leaf length, shoot, and dry weight. This showed that maize can be integrated with the tree species with the application of fertilizer to improve crop production.

\section{REFERENCES}

[1] Aziz, T., Rahmatullah, M.A., Maqsood, M. A., Tahir, I. A., and Cheema, M.A. (2006). Phosphorus 


\section{International Journal of Engineering Applied Sciences and Technology, 2020 Vol. 4, Issue 11, ISSN No. 2455-2143, Pages 414-420 \\ Published Online March 2020 in IJEAST (http://www.ijeast.com)}

utilization by six Brassica cultivars (Brassica juncea L.) from tri-calcium phosphate; a relatively insoluble P compound. Pakistan J. Bot., 38: (pg.1529-1538).

[2] Benton Jones Jr, J. (1998). Plant Nutrition Manual, CRC Press, New York, NY, USA, 1998.

[3] Boateng, S.A., Zichermann , J. and Kornahrens, M. (2006). Poultry manure effect on growth and yield of maize. West Africa J. Appl. Ecol., 9: (pg.1-11)

[4] Cadisch, G. and Giller, K. E. (1997). Driven by Nature: Plant Litter Quality and Decomposition. $C A B$ International, Wallingford, UK.

[5] Einhellig, F. A. (1986). Mechanisms and modes of action of allelochemicals. In: The science of allelopathy, (pg.171-187). Putnam, A. R. and C.S. Tang (eds.). Wiley, New York, USA

[6] Farooq, M., A. Wahid, Basra, S. M. A. and Din, I. U., (2009a). Improving water relations and gas exchange with brassinosteroids in rice under drought stress. J. Agron. Crop Sci., 195: (pg. 262-269).

[8] Farooq, M., S. Basra, M.A., Wahid, A., Ahmad, $\mathrm{N}$ and Saleem, B. A. (2009b). Improving the drought tolerance in rice (Oryza sativa L.) by exogenous application of salicylic acid. J. Agron. Crop Sci., 195: (pg. 237-246).

[9] Guzman, P. S., and Lamkey, K. R. (2000). Effective population size and genetic variability in the BS11 maize population. Crop Sci. 40:(pg. 38-46).

[10] Hasanuzzaman, M and Mahmood, H. (2014). "Nutrient leaching from leaf litter of cropland agroforest tree species of Bangladesh, Journal of Forest and Environmental Science, vol. 30, no. 2, (pg. 208-217).

[11] Hirzel, J., Matus, I., Novoa, F and Walter, I., (2007). Effect of poultry litter on silage maize (Zea mays L.) production and nutrient uptake. Spanish $J$. Agric. Res., 5: (pg. 102-109).

[12] Hossain, M., M. R. H., Siddique, Rahman, M. S., M., Hossain, Z. and Hasan, M. M. (2011). Nutrient dynamics associated with leaf litter decomposition of three agroforestry tree species (Azadirachta Indica, Dalbergia sissoo, and Melia azedarach) of Bangladesh, Journal of Forestry Research, vol. 22, no. 4, (pg. 577-582).
[13] Ismail , S., Fatih, O and Zeki, M. (2009). Nondestructive leaf area measurement in maize (Zea mays L.). Journal of Environmental Biology 5, (pg. 785-790).

[14] Kruse, M., Strandberg, M and Strandberg, B. (2000). Ecological Effects of Allelopathic Plants-a Review, p: 66. National Environmental Research Institute. NERI, Technical Report No. 315, Silkeborg, Available online at http://www2.dmu.dk/1_viden/2_publikationer/3.../rap porter/fr315.pd f (Accessed: 15 February 2013)

[15] Kyari, E. M., Abdulhameed, A., Ezra, A. G. (2019). Screening Of Four Rice Cultivars (Oryza sativa L.) For Resilience To Drought Stress And Low Inorganic Fertilizer. Researchjournali's Journal of Ecology 6. 4: (pg. 109-121).

[16] Mahmood, H. and Saberi, O. (2005). Degradation rate of leaf litter of Bruguieraparviflora of mangrove forest of Kuala Selangor, Malaysia, Indian Journal of Forestry, vol. 28, (pg. 144-149).

[17] Mahmood, H., Siddique, M. R. H., Abdullah, S. M. R. (2014). Nutrient dynamics associated with leaching and microbial decomposition of four abundant mangrove species leaf litter of the Sundarbans, Bangladesh, Wetlands, vol. 34, no. 3, (pg. 439-448).

[18] Marschner, H. (1995). Mineral Nutrition of Higher Plants. Academic Press International, San Diego, CA, USA Mengel, K. and E.A. Kirkby, 2001. Principles of Plant Nutrition, 5th edition. Kluwer Academic Publishers, London

[19] Mason, F. C. (1977). Decomposition, The Institute of Biology's Studies in Biology, Edward Arnold, London, UK.

[20] Mubarak, A. A., Badr, E. S and Ibrahim D. (2009). Decomposition and Nutrient Release from Various Tree Litters in a Sandy Soil of a Semi-arid Tropics. Desertification and Desert Cultivation Studies Institute, University of Khartoum, Shambat, Sudan. Sudan J. Des. Res. 1 (1):(pg. 36-55).

[21] Mubeen, K.., Iqbal, A.., Hussain, M., Zahoor, F., Sid- diqui, M.H., Mohsin, A.U., Bakht, H. F. S. G., Hanif, M. (2013). Impact of Nitrogen and Phospho- rus on the Growth, Yield and Quality of Maize (Zea mays L.) Fodder in Pakistan. Philipp. $J$. Crop Sci. 38,2: (pg. 43-46). 


\section{International Journal of Engineering Applied Sciences and Technology, 2020 Vol. 4, Issue 11, ISSN No. 2455-2143, Pages 414-420 \\ Published Online March 2020 in IJEAST (http://www.ijeast.com)}

[22] Muhammad, D and Khattak, R. A. (2009). Growth and nutrient concentration of maize in pressmud treated saline-sodic soils. Soil Environ., 28: (pg. 145-155).

[23] Mukaromah, A. S., Purwestri, Y. A and Fujii, Y. H. (2016) Determination of Allelopathic Potential in Mahogany (SwieteniamacrophyllaKing) Leaf Litter Using Sandwich Method. Indonesian Journal of Biotechnology, Vol. 21, No.2, (pg. 93-101).

[24] Palm, C. A., Myers R. J. K. and Nandwa, S. M. (1997). Combined use of organic and inorganic nutrient sources for soil fertility maintenance and replenishment. Pages 193-217. In: Buresh, R. J. and Sanchez, P. A (Eds). Replenishing soil fertility in Africa. SSSA Special Publication 51. Madison, WI, U. S. A.

[25] Park, S and Kang-Hyun, C. (2003). Nutrient leaching from leaf litter of emergent macrophyte (Zizanialatifolia) and the effects of water temperature on the leaching process. Korean Journal of Biological Sciences, vol. 7, (pg. 289-294).

[26] Semwal, R. L. Maikhuri, R. K., Rao, K. S., Sen, K. K. and Saxena, K. G. (2003). Leaf litter decomposition and nutrient release patterns of six multipurpose tree species of Central Himalaya, India," Biomass and Bioenergy, vol. 24, no. 1, (pg. 3-11).
[27] Rafiu, S. (2012). The potential of Azadirachta indica leave biomass as a nutrient source for maize cultivation in Tolon/Kumbungu District of Northern Ghana . A thesis submitted to the Department of Agroforestry, Kwame Nkrumah University of Science and Technology, in partial fulfilment of the requirements for the degree of Master Of Science In Agroforestry, Faculty of Renewable Natural Resources, Department of Agroforestry College of Agriculture and Natural Resources (BSc Agric Technology, UDS). December 2012

[28] Tilander, Y. (1993). Effects of mulching with Azadirachta indica and Albizia lebbeck leaves on the yield of sorghum under semi-arid conditions in Burkina Faso. Agroforestry Systems 24:(pg. 277293).

[29] Valiela, I., Teal, J. M., Allen, S. D., Van Etten, R., Goehringer, D. and Volkmann, S. (1985). Decomposition in salt marsh ecosystems:the phases and major factors affecting disappearance of above ground organic matter, Journal of Experimental Marine Biology and Ecology, vol. 89, no. 1, (pg. 2954).

[30] Verinumber, I. (1991). Agroforestry development in north-eastern Nigeria. Forest Ecology and Management 45(1):(pg.309-317). 